\title{
Peripartum Hysterectomies over a Fifteen-year Period
}

\section{Histerectomias periparto ao longo de um período de quinze anos}

\author{
Alessandra Dorigon ${ }^{1}$ Sérgio Hofmeister Martins-Costa1,2® José Geraldo Lopes Ramos ${ }^{1,2}$ J) \\ ${ }^{1}$ Hospital de Clínicas de Porto Alegre, Porto Alegre, RS, Brazil \\ 2 Department of Gynecology and Obstetrics, Faculty of Medicine, \\ Address for correspondence José Geraldo Lopes Ramos, Hospital de \\ Universidade Federal do Rio Grande do Sul, Porto Alegre, RS, Brazil \\ Clínicas de Porto Alegre, Rua Ramiro Barcelos, 2350, Escritório 1125, \\ Porto Alegre, RS, 90035-903, Brazil (e-mail: jramos@hcpa.edu.br).
}

Rev Bras Ginecol Obstet 2021;43(1):3-8.

\begin{abstract}
Keywords

- puerperal hysterectomy

- postpartum hemorrhage

- placenta accreta

- placenta previa
\end{abstract}

\section{Resumo}

\section{Palavras-chave}

- histerectomia puerperal

- hemorragia pós-parto

- placenta acreta

- placenta prévia
Objective To determine the indications and outcomes of peripartum hysterectomies performed at Hospital de Clínicas de Porto Alegre (a university hospital in Southern Brazil) during the past 15 years, and to analyze the clinical characteristics of the women submitted to this procedure.

Methods A cross-sectional study of 47 peripartum hysterectomies from 2005 to 2019.

Results The peripartum hysterectomies performed in our hospital were indicated mainly due to placenta accreta or suspicion thereof ( $44.7 \%$ of the cases), puerperal hemorrhage without placenta accreta (27.7\%), and infection (25.5\%). Total hysterectomies accounted for $63.8 \%$ of the cases, and we found no difference between total versus subtotal hysterectomies in the studied outcomes. Most hysterectomies were performed within 24 hours after delivery, and they were associated with placenta accreta, placenta previa, and older maternal age.

Conclusion Most (66.0\%) patients were admitted to the intensive care unit (ICU). Those who did not need it were significantly older, and had more placenta accreta, placenta previa, or previous Cesarean delivery.

Objetivo Determinar as indicações e os desfechos das histerectomias periparto realizadas no Hospital de Clínicas de Porto Alegre nos últimos 15 anos, bem como analisar as características clínicas das mulheres submetidas a esse procedimento.

Métodos Estudo transversal de 47 histerectomias periparto realizadas no período de 2005 a 2019.

Resultados Em nosso hospital, as histerectomias periparto foram indicadas principalmente por acretismo placentário ou sua suspeita (44,7\% dos casos), hemorragia puerperal sem acretismo placentário (27,7\%), e infecção (25,5\%). Histerectomias totais corresponderam a $63,8 \%$ dos casos, e não encontramos diferença entre histerectomia total e subtotal para os desfechos estudados. A maioria das histerectomias foi realizada dentro de 24 horas após o parto, o que estava associado a acretismo placentário, placenta prévia, e idade materna mais avançada.

Conclusão A maioria $(66,0 \%)$ das mulheres necessitou de internação em unidade de terapia intensiva (UTI); aquelas que não necessitaram eram significativamente mais velhas, e tinham mais acretismo placentário, placenta prévia, ou cesárea prévia. received

April 1, 2020

accepted

September 30, 2020
DOI https://doi.org/

10.1055/s-0040-1721354. ISSN 0100-7203. (c) 2021. Federação Brasileira das Associações de Ginecologia e Obstetrícia. All rights reserved.

This is an open access article published by Thieme under the terms of the Creative Commons Attribution License, permitting unrestricted use, distribution, and reproduction so long as the original work is properly cited. (https://creativecommons.org/licenses/by/4.0/)

Thieme Revinter Publicações Ltda., Rua do Matoso 170, Rio de Janeiro, RJ, CEP 20270-135, Brazil 


\section{Introduction}

In the history of Obstetrics, Horatio Storer performed the first hysterectomy on a gravid uterus in a live woman in 1869 due to a hemorrhage caused by a uterine tumor. ${ }^{1}$ The role of peripartum hysterectomy has changed ever since. In the 20th century, it was even indicated as a procedure for sterilization. ${ }^{2}$

Currently, peripartum hysterectomy is performed mainly in cases of abnormal placentation (predominantly placenta accreta) or life-threatening hemorrhage. ${ }^{3-5}$ A meta-analysis ${ }^{3}$ of 128 studies from low- to high-income countries estimated a weighted average of 0.9 peripartum hysterectomies per 1,000 births, and a maternal mortality rate of $5.2 \%$ after this procedure.

Both primary or repeat Cesarean sections are significantly associated with an increased risk of peripartum hysterectomy, not only due to abnormal placentation, but also due to uterine atony. ${ }^{6-9}$ Other risk factors are placenta previa (which is significantly associated with an increased likelihood of placenta accreta), advanced maternal age, twin pregnancy, chorioamnionitis, and puerperal infections. $3,7,8,10-12$

Women undergoing peripartum hysterectomy are at risk of postoperative complications, such as admission to the intensive care unit (ICU), blood transfusion, bladder and ureteral injury, reoperation, and wound complications. ${ }^{3,5,13-15}$

The objective of the present study was to analyze the peripartum hysterectomies performed at Hospital de Clínicas de Porto Alegre in the past 15 years to provide an evaluation of their main indications at our hospital. We also aimed to analyze the clinical characteristics of the patients submitted to this procedure.

\section{Methods}

The present cross-sectional study used retrospective data from the electronic health records stored in the database of Hospital de Clínicas de Porto Alegre from January 2005 (when the electronic health records were effectively implemented in our hospital) until August 2019 (final date of the search data). All 47 hysterectomies performed during this period due to pregnancy or puerperal complications were included. We chose to analyze some obstetric near-miss factors related to hysterectomy indications: hysterectomy time (up to 24 hours), admission to the ICU, use of antibiotics, type of hysterectomy (subtotal or total), and need of red-blood-cell transfusion. The prophylactic use of antibiotics was not considered, as it is part of the Cesareansection protocol. Only the use of antibiotics in the postpartum period was considered. The statistical analysis was performed using the Statistical Package for the Social Sciences (SPSS, IBM Corp., Armonk, NY, US) software. The Student $t$-test was used for the continuous variables, and the Fisher exact test, for the categorical variables. Values of $p<0.05$ were considered statistically significant. The present study was registered at Plataforma Brasil, the Brazilian unified database of research records involving human beings. Ethics approval was granted by the Ethics Commit- tee of Hospital de Clínicas de Porto Alegre. The authors signed a data-confidentiality agreement.

\section{Results}

The present study identified 47 cases of hysterectomies performed due to complications during pregnancy or the puerperium in the period from 2005 to 2019 in our hospital. Considering that 54,617 births occurred in this period, we estimate a rate of 0.87 peripartum hysterectomies per 1,000 births.

Maternal characteristics and previous and current pregnancy complications are shown in -Table 1. The mean maternal age was 31.2 years, the mean BMI was of $30.9 \mathrm{~kg} / \mathrm{m}^{2}$, and $59.6 \%$ of the patients had a previous Cesarean section. In the current pregnancy, the most frequent complications were intrauterine infection and/or puerperal infection and placenta accreta ( $44.7 \%$ and $42.6 \%$ of the cases respectively). Placenta previa was present in $27.7 \%$ of the patients.

- Table 2 shows the indications for Cesarean section and peripartum hysterectomy and the maternal and fetal outcomes. In total, $74.5 \%$ of the deliveries were by Cesarean section, and its main indication was placenta previa. The most frequent cause of hysterectomy was placenta accreta or suspicion thereof (44.7\% of peripartum hysterectomies), followed by postpartum hemorrhage without placenta accreta or suspicion (27.7\%) and puerperal infection (25.5\%). In addition, $63.8 \%$ of the hysterectomies were total, and $66.0 \%$ were performed within 24 hours

Table 1 Maternal characteristics and previous and current pregnancy complications

\begin{tabular}{|c|c|c|}
\hline $\begin{array}{l}\text { Maternal characteristics and } \\
\text { previous and current } \\
\text { pregnancy complications }\end{array}$ & $n$ & $\begin{array}{l}\text { Mean (standard } \\
\text { deviation) or \% (n) }\end{array}$ \\
\hline Maternal age (years) & 47 & $31.2(6.3)$ \\
\hline Previous cesarean section & 47 & $59.6 \%(28)$ \\
\hline Maternal weight $(\mathrm{kg})$ & 46 & $81.1(16.3)$ \\
\hline $\begin{array}{l}\text { Maternal Body Mass Index } \\
\left(\mathrm{kg} / \mathrm{m}^{2}\right)\end{array}$ & 46 & $30.9(6.0)$ \\
\hline $\begin{array}{l}\text { History of previous postpartum } \\
\text { hemorrhage }\end{array}$ & 47 & $8.5 \%(4)$ \\
\hline $\begin{array}{l}\text { Placenta previa in the current } \\
\text { pregnancy }\end{array}$ & 47 & $27.7 \%(13)$ \\
\hline $\begin{array}{l}\text { Placenta accreta in the current } \\
\text { pregnancy }\end{array}$ & 47 & $42.6 \%(20)$ \\
\hline $\begin{array}{l}\text { Preterm labor in the current } \\
\text { pregnancy }\end{array}$ & 47 & $19.1 \%(9)$ \\
\hline $\begin{array}{l}\text { Prelabor rupture of membranes } \\
\text { in the current pregnancy }\end{array}$ & 47 & $10.6 \%(5)$ \\
\hline $\begin{array}{l}\text { Cephalopelvic disproportion in } \\
\text { the current pregnancy }\end{array}$ & 47 & $8.5 \%(4)$ \\
\hline $\begin{array}{l}\text { Postpartum hemorrhage in the } \\
\text { current pregnancy }\end{array}$ & 47 & $55.3 \%(26)$ \\
\hline $\begin{array}{l}\text { Intrauterine infection and/or } \\
\text { puerperal infection }\end{array}$ & 47 & $44.7 \%(21)$ \\
\hline $\begin{array}{l}\text { Urinary tract infection in the } \\
\text { current pregnancy }\end{array}$ & 47 & $29.8 \%(14)$ \\
\hline
\end{tabular}


Table 2 Indications for Cesarean delivery and for peripartum hysterectomy and maternal and fetal outcomes

\begin{tabular}{|c|c|c|}
\hline $\begin{array}{l}\text { Indications for Cesarean delivery and for peripartum } \\
\text { hysterectomy and maternal and fetal outcomes }\end{array}$ & $\mathbf{n}$ & Mean (standard deviation) or \% (n) \\
\hline Cesarean delivery in the current pregnancy & 47 & $74.5 \%(35)$ \\
\hline \multicolumn{3}{|l|}{ Indication for cesarean delivery } \\
\hline Placenta previa & 35 & $37.1 \%(13)$ \\
\hline Fetal distress & 35 & $17.1 \%(6)$ \\
\hline Cephalopelvic disproportion & 35 & $11.4 \%(4)$ \\
\hline Placenta accreta or suspicion thereof with no placenta previa & 35 & $11.4 \%(4)$ \\
\hline \multicolumn{3}{|l|}{ Cause of peripartum hysterectomy } \\
\hline Placenta accreta or suspicion thereof & 47 & $44.7 \%(21)$ \\
\hline Postpartum hemorrhage with no placenta accreta nor suspicion thereof & 47 & $27.7 \%(13)$ \\
\hline Puerperal infection and suspicion thereof & 47 & $25.5 \%(12)$ \\
\hline Uterine rupture & 47 & $2.1 \%(1)$ \\
\hline Total hysterectomy & 47 & $63.8 \%(30)$ \\
\hline Hysterectomy within 24 hours after delivery & 47 & $66.0 \%(31)$ \\
\hline $\begin{array}{l}\text { Antibiotic therapy during delivery or hysterectomy } \\
\text { hospitalizations or in the postpartum period }\end{array}$ & 47 & $59.6 \%(28)$ \\
\hline Transfusion of red blood cells & 47 & $76.6 \%(36)$ \\
\hline Intensive care admission & 47 & $66.0 \%(31)$ \\
\hline Gestational age at delivery (weeks) & 47 & $37.2(3.2)$ \\
\hline Male newborn & 45 & $35.6 \%(16)$ \\
\hline Birth weight $(\mathrm{kg})$ & 45 & $2.876(0.686)$ \\
\hline
\end{tabular}

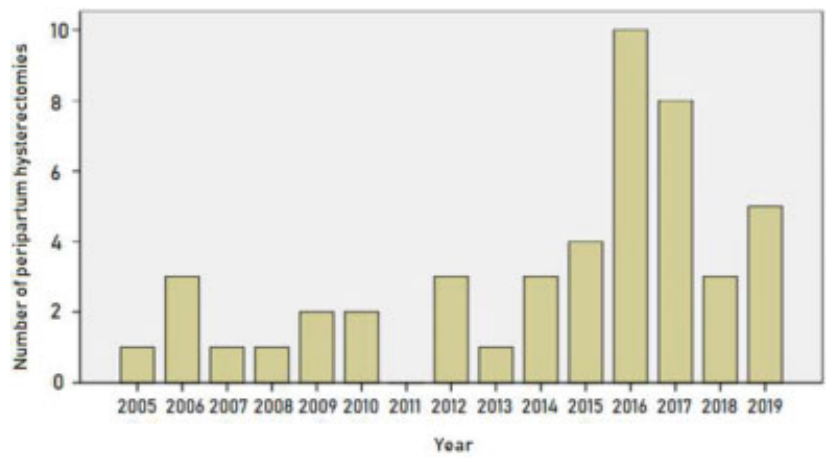

Fig. 1 Timeline of peripartum hysterectomies.

after delivery. Most patients required red-blood-cell transfusion and admission to the ICU (76.6\% and $66.0 \%$ respectively). The mean gestational age at delivery was 37.2 weeks.

-Fig. 1 shows the annual distribution of peripartum hysterectomies in our hospital from 2005 to 2019. There was a peak in the number of hysterectomies in 2016 and 2017, and a subsequent reduction in 2018.

-Table 3 compares peripartum hysterectomy within 24 hours after delivery with hysterectomy performed more than 24 hours after delivery. Earlier hysterectomy was associated with older maternal age (33.3 versus 27.1 years; $p=0.001$ ), placenta accreta ( $54.8 \%$ versus $18.8 \% ; p=0.029$ ), and placenta previa ( $38.7 \%$ versus $6.3 \% ; p=0.036$ ). Premature rupture of membranes was less common in cases of earlier peripartum hysterectomy (3.2\% versus $25.0 \% ; p=0.040$ ).

- Table 4 shows that patients who were not admitted to the ICU were significantly older (33.3 versus 30.1 years; $p=0.045$ ), had a higher prevalence of placenta accreta (62.5\% versus $32.3 \% ; p=$. 065$)$, of placenta previa $(50.0 \%$ versus $16.1 \% ; p=0.020)$, and of previous Cesarean section (87.5\% versus $45.2 \% ; p=0.006$ ).

We compared the use of postpartum antibiotics during the hospitalization with patients who did not use antibiotic therapy. We can see that the women treated with antibiotics were younger (29.5 versus 33.7 years; $p=0.024$ ) and had preterm labor more frequently, but that was not statistically significant ( $28.6 \%$ versus $5.3 \% ; p=0.064$ ). We 
6 Peripartum Hysterectomies over a Fifteen-year Period Dorigon et al.

Table 3 Peripartum hysterectomy within 24 hours after delivery

\begin{tabular}{|c|c|c|c|c|c|}
\hline & \multicolumn{2}{|c|}{$\begin{array}{l}\text { Hysterectomy after } \\
24 \text { h after delivery }\end{array}$} & \multicolumn{2}{|c|}{$\begin{array}{l}\text { Hysterectomy within } \\
24 \mathrm{~h} \text { after delivery }\end{array}$} & \multirow[t]{2}{*}{ p-value } \\
\hline & $\mathrm{n}$ & $\begin{array}{l}\text { Mean (standard } \\
\text { deviation) or \% (n) }\end{array}$ & $\mathrm{n}$ & $\begin{array}{l}\text { Mean (standard } \\
\text { deviation) or \% (n) }\end{array}$ & \\
\hline Previous Cesarean section & 16 & $43.8 \%(7)$ & 31 & $67.7 \%(21)$ & 0.131 \\
\hline $\begin{array}{l}\text { History of previous } \\
\text { postpartum hemorrhage }\end{array}$ & 16 & $0 \%(0)$ & 31 & $12.9 \%(4)$ & 0.284 \\
\hline Placenta previa & 16 & $6.3 \%(1)$ & 31 & $38.7 \%(12)$ & 0.036 \\
\hline Placenta accreta & 16 & $18.8 \%(3)$ & 31 & $54.8 \%(17)$ & 0.029 \\
\hline Prelabor rupture of membranes & 16 & $25.0 \%(4)$ & 31 & $3.2 \%(1)$ & 0.040 \\
\hline Preterm labor & 16 & $31.3 \%(5)$ & 31 & $12.9 \%(4)$ & 0.239 \\
\hline Cephalopelvic disproportion & 16 & $12.5 \%(2)$ & 31 & $6.5 \%(2)$ & 0.597 \\
\hline Maternal age (years) & 16 & $27.1(6.6)$ & 31 & $33.3(5.1)$ & 0.001 \\
\hline Maternal Body Mass Index $\left(\mathrm{kg} / \mathrm{m}^{2}\right)$ & 15 & $30.5(6.2)$ & 31 & $31.1(6.0)$ & 0.742 \\
\hline Gestational age at delivery (weeks) & 16 & $37.3(3.7)$ & 31 & $37.1(3.0)$ & 0.835 \\
\hline Birth weight $(\mathrm{kg})$ & 14 & $3.068(0.768)$ & 31 & $2.790(0.640)$ & 0.212 \\
\hline
\end{tabular}

Table 4 Admission to the intensive care unit (ICU)

\begin{tabular}{|c|c|c|c|c|c|}
\hline & \multicolumn{2}{|c|}{ NO ICU ADMISSION } & \multicolumn{2}{|c|}{ ICU ADMISSION } & \multirow[t]{2}{*}{ p-value } \\
\hline & $\mathrm{n}$ & $\begin{array}{l}\text { Mean (standard } \\
\text { deviation) or \% (n) }\end{array}$ & $\mathrm{n}$ & $\begin{array}{l}\text { Mean (standard } \\
\text { deviation) or \% (n) }\end{array}$ & \\
\hline Previous Cesarean section & 16 & $87.5 \%(14)$ & 31 & $45.2 \%(14)$ & 0.006 \\
\hline $\begin{array}{l}\text { History of previous } \\
\text { postpartum hemorrhage }\end{array}$ & 16 & $12.5 \%(2)$ & 31 & $6.5 \%(2)$ & 0.597 \\
\hline Placenta previa & 16 & $50.0 \%(8)$ & 31 & $16.1 \%(5)$ & 0.020 \\
\hline Placenta accreta & 16 & $62.5 \%(10)$ & 31 & $32.3 \%(10)$ & 0.065 \\
\hline Prelabor rupture of membranes & 16 & $12.5 \%(2)$ & 31 & $9.7 \%(3)$ & 1.000 \\
\hline Preterm labor & 16 & $18.8 \%(3)$ & 31 & $19.4 \%(6)$ & 1.000 \\
\hline Cephalopelvic disproportion & 16 & $0 \%(0)$ & 31 & $12.9 \%(4)$ & 0.284 \\
\hline Maternal age (years) & 16 & $33.3(3.5)$ & 31 & $30.1(7.2)$ & 0.045 \\
\hline Maternal Body Mass Index (kg/m²) & 16 & $30.8(6.9)$ & 30 & $31.0(5.6)$ & 0.894 \\
\hline Gestational age at delivery (weeks) & 16 & $36.8(2.5)$ & 31 & $37.4(3.6)$ & 0.595 \\
\hline Birth weight (kg) & 16 & $2.650(0.493)$ & 29 & $3.001(0.751)$ & 0.101 \\
\hline
\end{tabular}

found no statistically significant difference between total and subtotal hysterectomy for the clinical factors analyzed. Blood transfusion was not associated with any of these factors either.

\section{Discussion}

In the present study, we found that the rate of peripartum hysterectomies was of 0.87 per 1,000 births. This number is very similar to the weighted average peripartum hysterectomy of 0.9 per 1,000 births provided by the aforementioned metaanalysis, ${ }^{3}$ although still above many estimates from highincome countries. $^{3-5}$

The main cause of peripartum hysterectomy in the present study - placenta accreta or suspicion thereof - was responsible for $44.7 \%$ of the cases. Although our hospital is a referral center for these patients, this finding is consistent with systematic reviews that report placental abnormalities as the most common indication, followed by uterine atony and other causes, such as uterine rupture and infection (including chorioamnionitis and endometritis). ${ }^{3-5}$ However, the fact that $25.5 \%$ of our peripartum hysterectomies are due to infection contrasts with most other series, in which it accounts for $2 \%$ or less of hysterectomies. ${ }^{3-5,16}$

In the present study, $74.5 \%$ of deliveries were Cesarean sections, and their main indication was placenta previa. This may be related both to the increased risk of peripartum hysterectomy after primary or repeat Cesarean section, and to the strong association between placenta previa and placenta accreta. ${ }^{6-9,11,12}$ At Hospital de Clínicas de Porto Alegre, the rate of Cesarean section in the same period was of $34.2 \%$.

Total hysterectomy represented $63.8 \%$ of the hysterectomies performed in our patients. The proportion of total versus subtotal hysterectomies varies in different studies. 
Two systematic reviews reported rates of $51.1 \%^{3}$ and $52.2 \%^{5}$ of total hysterectomies, but large series ${ }^{14}$ have also reported higher proportions. In addition, in the present study there was no significant difference between total and subtotal hysterectomy for the analyzed outcomes. The comparison between the two techniques produced controversial results, and, while some series of studies found statistically significant differences $^{14}$, others did not. ${ }^{13,17}$

Blood transfusion and ICU admission were necessary for $76.6 \%$ and $66.0 \%$ of the patients respectively. According to systematic reviews and other studies, many patients undergoing peripartum hysterectomy require blood transfusion and ICU admission. 3,5,13-15

We observed that the use of antibiotic therapy during the hospitalization was associated with premature labor, which was 5.4 times more frequent in women treated with antibiotics ( $28.6 \%$ versus $5.3 \%$ ), although the $p$-value was not statistically significant (0.064). Inflammation and infection are part of the pathogenesis of premature labor, which possibly explains a greater need for antibiotics in this group of patients. Another discussion point would be if the use of antepartum antibiotic therapy could select infecting bacteria in the postpartum period.

The finding that hysterectomy more than 24 hours after birth was associated with premature rupture of membranes may have been biased by a small number of cases in each group ( 4 after 24 hours versus 1 within 24 hours). On the other hand, the association of hysterectomy performed in the first 24 hours after delivery with placenta accreta, placenta previa and more advanced maternal age is expected. Many cases of placenta accreta in the present series were suspected before birth, leading to early intervention. Some were even preprogrammed.

In addition, women in the present series who were not admitted to the ICU were also significantly older and more likely to have placenta previa or undergo Cesarean section. Although the difference was not statistically significant $(p=0.065), 62.5 \%$ of these patients had placenta accreta versus $32.3 \%$ of those who were admitted to the ICU. The prenatal suspicion of cases of placenta accreta in the present series enabled the adoption of special measures, possibly reducing maternal morbidity. When placenta accreta is suspected, the care of a multidisciplinary team and not attempting placenta removal both improve the results. ${ }^{18-20}$ In addition, placenta previa, advanced maternal age and Cesarean section are associated with placenta accreta. $^{11,12}$

There were two maternal deaths in the present series, one due to hemorrhagic shock and the other due to septic shock. The mortality rate for peripartum hysterectomies was of $4.3 \%$, which is lower than the $5.2 \%$ estimate of a metaanalysis $^{3}$ of 128 studies from different countries (11.9\% in low- and middle-to-low-income countries, compared with $2.5 \%$ in high- and middle-to-high-income countries).

\section{Conclusion}

We found an expressive association between peripartum hysterectomy and placenta previa and placenta accreta, which was an important factor in the indication of hysterectomy. This situation has been advancing in Brazil in recent years because of the excessive performance of Cesarean sections.

\section{Contributors}

All of the authors contributed with the project and data interpretation, the writing of the article, the critical review of the intellectual content, and with the final approval of the version to be published.

\section{Conflicts of Interest}

The authors have no conflict of interests to declare.

\section{References}

1 Durfee RB. Evolution of cesarean hysterectomy. Clin Obstet Gynecol. 1969;12(03):575-589. Doi: 10.1097/00003081-196909000-00002

2 Davis ME. Complete cesarean hysterectomy; a logical advance in modern obstetric surgery. Am J Obstet Gynecol. 1951;62(04): 838-853. Doi: 10.1016/0002-9378(51)90174-3

3 van den Akker T, Brobbel C, Dekkers OM, Bloemenkamp KW. Prevalence, indications, risk indicators, and outcomes of emergency peripartum hysterectomy worldwide: a systematic review and meta-analysis. Obstet Gynecol. 2016;128(06):1281-1294. Doi: 10.1097/AOG.0000000000001736

4 de la Cruz CZ, Thompson EL, O'Rourke K, Nembhard WN. Cesarean section and the risk of emergency peripartum hysterectomy in high-income countries: a systematic review. Arch Gynecol Obstet. 2015;292(06):1201-1215. Doi: 10.1007/s00404-015-3790-2

5 Rossi AC, Lee RH, Chmait RH. Emergency postpartum hysterectomy for uncontrolled postpartum bleeding: a systematic review. Obstet Gynecol. 2010;115(03):637-644. Doi: 10.1097/AOG.0b013e3181cfc007

6 Bateman BT, Mhyre JM, Callaghan WM, Kuklina EV. Peripartum hysterectomy in the United States: nationwide 14 year experience. Am J Obstet Gynecol. 2012;206(01):63.e1-63.e8. Doi: 10.1016/j.ajog.2011.07.030

7 Whiteman MK, Kuklina E, Hillis SD, Jamieson DJ, Meikle SF, Posner SF, Marchbanks PA. Incidence and determinants of peripartum hysterectomy. Obstet Gynecol. 2006;108(06):1486-1492. Doi: 10.1097/01.AOG.0000245445.36116.c6

8 Knight M, Kurinczuk JJ, Spark P, Brocklehurst PUnited Kingdom Obstetric Surveillance System Steering Committee. Cesarean delivery and peripartum hysterectomy. Obstet Gynecol. 2008; 111(01):97-105. Doi: 10.1097/01.AOG.0000296658.83240.6d

9 Kacmar J, Bhimani L, Boyd M, Shah-Hosseini R, Peipert J. Route of delivery as a risk factor for emergent peripartum hysterectomy: a case-control study. Obstet Gynecol. 2003;102(01):141-145. Doi: 10.1016/s0029-7844(03)00404-6

10 Bodelon C, Bernabe-Ortiz A, Schiff MA, Reed SD. Factors associated with peripartum hysterectomy. Obstet Gynecol. 2009;114(01): 115-123. Doi: 10.1097/AOG.0b013e3181a81cdd

11 Miller DA, Chollet JA, Goodwin TM. Clinical risk factors for placenta previa-placenta accreta. Am J Obstet Gynecol. 1997; 177(01):210-214. Doi: 10.1016/s0002-9378(97)70463-0

12 Silver RM, Landon MB, Rouse DJ, Leveno KJ, Spong CY, Thom EA, et al; National Institute of Child Health and Human Development Maternal-Fetal Medicine Units Network. Maternal morbidity associated with multiple repeat cesarean deliveries. Obstet Gynecol. 2006;107 (06):1226-1232. Doi: 10.1097/01.AOG.0000219750.79480.84

13 Knight MUKOSS. Peripartum hysterectomy in the UK: management and outcomes of the associated haemorrhage. BJOG. 2007; 114(11):1380-1387. Doi: 10.1111/j.1471-0528.2007.01507.x

14 Wright JD, Devine P, Shah M, Gaddipati S, Lewin SN, Simpson LL, et al. Morbidity and mortality of peripartum hysterectomy. Obstet Gynecol. 2010;115(06):1187-1193. Doi: 10.1097/AOG.0b013e3181df94fb

15 Shellhaas CS, Gilbert S, Landon MB, Varner MW, Leveno KJ, Hauth JC, et al; Eunice Kennedy Shriver National Institutes of Health and 
8 Peripartum Hysterectomies over a Fifteen-year Period Dorigon et al.

Human Development Maternal-Fetal Medicine Units Network. The frequency and complication rates of hysterectomy accompanying cesarean delivery. Obstet Gynecol. 2009;114(2 Pt 1):224-229. Doi: 10.1097/AOG.0b013e3181ad9442

16 Cheng HC, Pelecanos A, Sekar R. Review of peripartum hysterectomy rates at a tertiary Australian hospital. Aust N Z J Obstet Gynaecol. 2016;56(06):614-618. Doi: 10.1111/ajo.12519

17 Imudia AN, Hobson DT, Awonuga AO, Diamond MP, Bahado-Singh RO. Determinants and complications of emergent cesarean hysterectomy: supracervical vs total hysterectomy. Am J Obstet Gynecol. 2010;203(03):221.e1-221.e5. Doi: 10.1016/j.ajog.2010.04.007

18 Eller AG, Bennett MA, Sharshiner M, Masheter C, Soisson AP, Dodson M, Silver RM. Maternal morbidity in cases of placenta accreta managed by a multidisciplinary care team compared with standard obstetric care. Obstet Gynecol. 2011;117(2 Pt 1):331-337. Doi: 10.1097/aog.0b013e3182051db2

19 Fitzpatrick KE, Sellers S, Spark P, Kurinczuk JJ, Brocklehurst P, Knight M. The management and outcomes of placenta accreta, increta, and percreta in the UK: a population-based descriptive study. BJOG. 2014;121(01):62-70, discussion 70-71. Doi: 10.1111/1471-0528.12405

20 Eller AG, Porter TF, Soisson P, Silver RM. Optimal management strategies for placenta accreta. BJOG. 2009;116(05):648-654. Doi: 10.1111/j.1471-0528.2008.02037.x 